\title{
Competitiveness of Turkey in Eurasia: A Comparison with CIS Countries
}

\author{
Hacer Simay Karaalp, Pamukkale University
}

\begin{abstract}
The main aim of this paper is to examine international competitiveness of Turkey both in world market and CIS (Commonwealth of Independent States) in comparison with Azerbaijan, Belarus, Georgia, Kazakhstan, Kyrgyz Republic, Moldova, Ukraine, Russia and to determine the value of trade between Turkey and CIS countries. The Revealed Comparative Advantage, Grubel-Lloyd (IIT) and Trade Intensity indices were calculated for sixteen commodity groups over the period 1996-2008 by using WTO data. The results suggest that Turkey is more competitive in CIS market and has comparative advantage in various products. Turkey has comparative advantage not only in agricultural products, food, manufactures, automotive products, textile and clothing as the world market but also in chemicals, pharmaceuticals, machinery-transport equipment, office-telecom equipment and telecommunications vis-à-vis CIS countries. CIS countries exhibit similar comparative advantages in the world market. CIS countries have comparative advantage particularly in fuels and mining products, agricultural products, food, iron and steel but in a decreasing trend. The IIT results indicate that while Turkey approaches intra-industry specialization in agricultural products, food and textile but also manufacture products such as iron and steel, telecommunications equipment, machinerytransport and automotive products. CIS countries' economy indicates increasing intra-industry trade in agriculture products, food manufactures, iron and steel. It is found that there is an intense relationship between Turkey and CIS countries except Belarus. Bilateral trade flow between Turkey and Azerbaijan, Kyrgyz Republic and the Georgia is extremely larger than these countries' importance in world trade.
\end{abstract}

JEL Codes: F10, F14, F13

\section{Introduction}

After 1980's many important changes occurred in the world economy with the globalization. Many countries eliminated its borders and entered to global markets. As a result, the size of the world trade in goods and services has dramatically increased with the technological progress. Moreover, financial flows became globalized in the 1990s. However globalization caused various massive changes in economic specialization, income inequality and poverty not only just among the countries but also within countries and regions. World economy has opened to new geographies since the effect of globalization. In addition to old industrial countries new countries attended to the global economy and integrated into the world market. More integrated into the world market and the higher degree of economic liberalization indicates increased growth rates, trade flows and competitiveness. During this period transition countries of the CIS were not left out of the globalization process. After the break up of the USSR in 1991, 15 independent countries established. During this period The Commonwealth of Independent States (CIS) was founded in 1991 after the dissolution of the Soviet Union with the 12 member states (Armenia, Azerbaijan, Belarus, Georgia, Kazakhstan, Kyrgyzstan, Moldova, Russia, Tajikistan, Turkmenistan, Ukraine, and Uzbekistan) which Georgia withdrawal from the CIS in 18th August 2009. Upon its foundation, members adopted the Alma-Ata Declaration, which confirmed the promise of the former republics to cooperate in various fields of external and internal policies, and announced the guarantees for implementation of the international commitments of the former Soviet Union (IONP, 2009).

The main objective of this study is to analyze international competitiveness of Turkey both in world market and CIS (Commonwealth of Independent States) market in comparison with the CIS countries and to determine whether the value and extent of trade between countries and 
trade overlap for the given products. The study covers the 1996-2008 period and sixteen product levels relying mainly on WTO's trade database. All product groups are defined according to Revision 3 of the Standard International Trade Classification (SITC) by WTO. Some countries discarded from the study due to the incomplete data (Tajikistan, Turkmenistan and Uzbekistan) and concentrated instead on Azerbaijan, Armenia, Belarus, Georgia, Kazakhstan, Kyrgyz Republic, Moldova, Tajikistan, Russia and as well as Turkey.

In order to identify the products that hold the most promise of being the leading export sectors, Turkey's comparative advantage vis-à-vis CIS countries and world Balassa's Index of Revealed Comparative Advantage (RCA), to analyze intra and inter-industry specialization of Turkey's and CIS countries' trade Grubel-Lloyd Indices and to determine the value of trade between Turkey and CIS countries Trade Intensity Index and are calculated.

The paper is divided into five main sections. The following section briefly focuses on the economic relations between Turkey and CIS. The third part describes the methodology for assessing Turkey's competitiveness with the CIS countries, Revealed Comparative Advantage (RCA), Grubel-Lloyd Index of Intra-industry Trade (IIT) and Trade Intensity Index will be given. The results of the analysis will be evaluated in the fourth section. Conclusion of the study and inferences will be assessed and interpreted in the final section.

\section{Structure of CIS Foreign Trade and Economic Relations between Turkey and CIS countries}

As a result of the Trade Development Strategy with Neighboring and Region Countries, Turkey started to look for new ways to improve its trade and create a fair trading environment in the Middle East, South East Europe, Black Sea, Caucasus and Central Asia (WTO, 2003). Since 1990's, after the break up of USSR Russia and the Turkic countries have been playing an increasing role in Turkey's external economic relations. Economic relations between Turkey and CIS have increased over the period, especially after 2003. While Turkey's total export to the CIS was $2.663 .908 .726 \$$ (11.47\% of Turkey's total export) and total import form CIS was $3.074 .152 .966 \$$ (7.05\% of Turkey's total import) in 1996. Turkey's export to CIS has increased $423 \%$ from 1996 to 2008 and reached to $13.938 .225 .914 \$$ and import has increased sharply to 42.613.878.879\$ in 2008. The share of export to the CIS countries in Turkey started to increase since 2006 and reached $10.56 \%$ in 2008. Turkey's import from CIS countries increased significantly and constituted $21.10 \%$ and $18.48 \%$ of Turkish world import in 2008 and 2009 respectively (Turkstat, 2010). Russia is the main trade partner of Turkey among the CIS countries which Turkey had 6,483,003,596\$ export and 31,364,476,862\$ import in 2008. Other biggest export and import partners of Turkey are Ukraine, Azerbaijan, Georgia and Kazakhstan. The only CIS country which Turkey has no trade relation is Armenia. The border has been closed since 1993 due to the politic reasons.

Turkish exports to the CIS countries concentrated heavily on the manufactured goods classified chiefly by material (SITC 6) and export of machinery and transport equipment (SITC 7) which has been increasing since 2000 especially to Ukraine, Russia, Uzbekistan, and Kazakhstan, Chemicals and related products (SITC 5) and Miscellaneous manufactured articles (SITC 8). Turkish import from the CIS countries concentrated heavily on manufactured goods classified chiefly by material (SITC 6), Crude materials, inedible, except fuels (SITC 2), Mineral fuels, lubricants and related materials (SITC 3), Food and live animals (SITC 0) (Turkstat, 2010).

\section{Methodology and Data}

\subsection{The Revealed Comparative Advantage Index,}

Revealed Comparative Advantage (RCA) index, as developed by Balassa (1965) compares 
the share of the export of the ith good in a given country's total exports to the share of that export good in world or a set of countries exports. The RCA index can be written as:

RCAij $=($ Xij / Xit $) /($ Xwj / Xwt $)$

where, xij and xwj represents the values of country i's exports of product $j$ and world exports of product $\mathrm{j}$ and where Xit and Xwt refer to the country's total exports and world or set of countries (CIS) total exports. A value of index greater than unity indicates that the country in question has comparative advantage in the product. If the value is less than unity implies that the country has a revealed comparative disadvantage in the product. (Fertö and Hubbard (2003), Havrila and Gunawardana (2003), Utkulu and Seymen (2004)).

\subsection{Grubel-Lloyd Index of Intra-industry Trade}

IIT index proposed by Grubel and Lloyd (1975) is based on measuring the trade overlap for a given industry (Erlat et.al., 2007). Intra-industry exchange produces extra gains from international trade over. It suggests how and to what extent the economy in question is already integrated into the world market and the degree of liberalization that the economy has already realized throughout the economic development process (Y1lmaz, 2003:13). Index is often computed using the following formulae:

$\operatorname{IIT}_{\mathrm{i}}=1-\left(\left|\mathrm{X}_{\mathrm{i}}-\mathrm{M}_{\mathrm{i}}\right| /\left(\mathrm{X}_{\mathrm{i}}+\mathrm{M}_{\mathrm{i}}\right)\right)$

where, $\mathrm{Xi}$ is export of the ith industry and Mi is import of the ith industry. IIT index has a value range between 0 and 1 or 0 and 100 in percentage form. A large value implies greater trade between firms in the same industry.

\subsection{Trade Intensity Index}

The trade intensity index $(\mathrm{T})$ is used to determine whether the value of trade between two countries is greater or smaller than would be expected on the basis of their importance in world trade (Hoekman et.al., 2003).

$\mathrm{Tij}=(\mathrm{xij} / \mathrm{Xit}) /(\mathrm{xwj} / \mathrm{Xwt})$

where, xij and xwj represents the values of country i's exports to country $j$ and of world exports to country $\mathrm{j}$ and Xit and Xwt refer to country i's total exports and total world exports respectively. A value of index more than unity indicates a bilateral trade flow that is larger than expected given the partner country's importance in world trade. An index of more than one implies an 'intense' trade relationship. If the value is less than unity indicates bilateral trade flow is smaller than expected.

\section{Empirical Results}

\subsection{Revealed Comparative Advantage}

According to the results Turkey has revealed comparative advantage in manufactures which has an increasing trend especially after 1999. RCA of Turkish manufacture products was 1.03 in 1996 and increased 1.21 in 2008. The most significant products of Turkish manufacture industry in the world trade are textiles, and clothing, iron and steel which have high revealed comparative advantage during the time period. Although the high value of RCA Turkey's advantages in textile decreased since 2001. The RCA of Turkey in clothing sector was 8.50 in 1996 which is the most competitive sector of the Turkish economy as well as textile, has decreased dramatically since 1996 and declined to 4.57 in 2008. Turkey has a significant and rising comparative advantage in automotive products since 2003 . While automotive products' RCA value was 0.37 in 1996 increased to 1.76 in 2008. Turkey has a decreasing comparative advantage in agricultural products and food in the world trade. The RCA value was 1.90 and 2.21 in 1996, decreased to 1.02 and 1.17 respectively. However Turkey has comparative disadvantage in fuels and mining products, fuels, chemicals (with an increasing trend), pharmaceuticals, machinery and transport equipment (which has an increasing trend, Turkey 
will have comparative advantage in the near future), office and telecom equipment, electronic data processing and office equipment, telecommunications equipment and integrated circuits and electronic components in the world market.

Turkey has comparative advantage in agricultural products, food, manufactures, automotive products, textile and clothing, chemicals, pharmaceuticals, machinery and transport equipment, office and telecom equipment, telecommunications equipment with respect to CIS countries. However comparative advantage of agricultural products, food, pharmaceuticals, office and telecom equipment, telecommunications equipment and clothing products have decreasing trend during the period with RCA value of 2.79, 3.95, 8.23, 2.54, 3.70, 20.50 in 1996 and decreased to $1.68,2.27,3.44,2.12,2.28,12.54$ in 2008. Products which have increasing comparative advantage vis a vis CIS countries are manufactures, chemicals, machinery and transport equipment, automotive products and textile with RCA value of 3.27, 1.37, 2.50, 2.96, 8.78 in 1996 and 3.29, 2.04, 5.86, 14.55,47.58 in 2008.

The most prosperity country among the CIS countries Russia has comparative advantage in fuels and mining products, fuels, iron and steel in a decreasing trend. The RCA of these products was 4.90, 5.23 and 3.38 in 1996 and decreased 3.33, 3.67 and 1.92 in 2008. Ukraine has a decreasing comparative advantage especially in iron and steel. Other competitive sectors are agricultural products and food with an increasing trend during the period with the RCA value of 1.79 and 2.14 in 1996 and 2.02 and 2.32 in 2008 respectively. Whereas Ukraine lost its comparative advantage and has comparative disadvantage in the fuels and mining products. Moldova has revealed comparative advantage in agricultural products and food in a decreasing trend and clothing sector with an increasing trend with RCA 1.41 in 1996 and 7.44 in 2008; textile sector also became competitive since 2005 and its RCA increased to 1.97 in 2008. Belarus has comparative advantage in a set of diverse products which are agricultural products, food, fuels and mining products, fuels, iron and steel, textiles but in a decreasing trend during the period except chemicals (RCA was 137 in 1996, 1.44 in 2008). The RCA of products decreased to $0.96,0.97,1.73,2.11,1.37$ and 1.15 in 2008 respectively. However Belarus lost its comparative advantage in clothing since 2005. Georgia has comparative advantage in agricultural products, food, fuels and mining products, iron and steel during the period in a decreasing trend with the RCA value of 2.91, 3.31, 2.33, 5.42 in 1996 and 2.19, 2.38, 1.06, 5.35 in 2008 respectively. Georgia lost its revealed comparative advantage in fuel since 1999. Kazakhstan has revealed comparative advantage in fuels and mining, fuels and iron and steel in a decreasing trend with a RCA value 3.68, 3.86, 2.26 in 2008 respectively. Moreover Kazakhstan had comparative advantage in agricultural products and food in 1996-97 but have comparative disadvantage since 1998. Fuels and mining and fuels are the most competitive products of Azerbaijan during the period but in a decreasing trend as most of the other CIS countries. Azerbaijan lost its competitiveness in agricultural products vis a vis world market since 1999 as Kazakhstan. Its RCA was 1.14 in 1996 but dropped to 0.22 in 2008. Unfortunately Kyrgyz Republic has not a stable result for its RCA in the time period but nevertheless it has comparative advantage in agricultural products, food (with a decreasing trend) fuels and mining and fuels (for the last three years) with RCA value of 2.37, 2.46, 1.83, 2.08 in 2008. Kyrgyz Republic has become comparative advantage in clothing since 2004 in the world market. Its RCA value was increased 0.54 from 1996 to 3.25 in 2008.

\subsection{Index of Intra-industry Trade}

Turkey only eight of sixteen products (agricultural products, food, manufactures, iron and steel, telecommunications equipment, textiles, machinery transport and automotive after 2001) have IIT which exceed $50 \%$ for the period as a whole. IIT showed an increasing trend throughout the period in food, manufactures, telecommunications equipment and textile. IIT showed an increase from 2001 onwards and reached the level of 0.95 and 0.86 in automotive products and machinery and transport equipment respectively. Turkey approaches intraindustry specialization in automotive products and machinery and transport equipment for the 
last eight years. Russian economy indicates the characteristics of intra-industry mainly in agricultural products, food, manufactures and chemicals. Ukraine's trade in five sectors of production creates the intra-industry type of specialization in agricultural products, food, manufactures, chemicals and Machinery and transport equipment and clothing has an ITT value that exceeds $50 \%$ for the last four years. IIT results for Moldova economy reflects intraindustry specialization only in agricultural products and food increasingly after 2000 and manufactures for 1996-2002. For Belarus ITT showed an increase in agricultural products, food, fuels and mining products, fuels (after 1999), iron and steel, integrated circuits and electronic components (after 1998), automotive products and textiles whereas a decrease in chemicals, machinery and transport equipment. Georgia approaches inter-industry specialization most of the products in the whole period except iron and steel. Value of IIT in agricultural products, food, fuels and mining products was higher for the period 1998-2005. Kazakhstan economy reflects mainly increasing intra-industry specialization in agricultural products, food throughout the period and iron and steel since 2001. The only sector which has higher IIT in Azerbaijan is agricultural products and food for the last six years. Kyrgyz Republic economy indicates intra-industry trade mainly in agricultural products, food and partly in textiles.

\subsection{Trade Intensity}

The results indicate that trade intensity between Turkey and CIS countries over the period is more than unity except Belarus. Trade intensity between Turkey and Russia has decreased throughout the period and indicate a steady decreasing trend after 2003 which was 5.10 in 1996 and dropped to 2.70 in 2008 . A steady intense trade relationship found between Turkey and Ukraine over the whole period between 1996 (3.54) and 2008 (3.11). Over the same period the values of trade intensity between Turkey and Moldova has increased from 3.13 to 4.93 . The trade intensity between Turkey and Georgia decreased from 1996 (37.36) to 2005 (15.58). An intense trade relationship found between Turkey and Kazakhstan which has been decreasing whole period from its highest level in 1997 (10.42) to 2.86 in 2008. After a dramatic decline of the value of trade intensity between Turkey and Azerbaijan from 1996 (58.08) to 2004 (16.77), trade intensity index showed a steady increase from 2005 onwards and reached 26.80 in 2008. Although trade intensity between Turkey and Kyrgyz Republic has irregular trend throughout the period, the results show an 'intense' trade relationship between them.

\section{Conclusions}

The results indicate that Turkey has strong comparative advantage in agricultural products, food, manufactures, textiles, clothing, iron and steel and automotive products especially for the last six years. However Turkey's comparative disadvantage has been decreasing in machinery and transport equipment and chemicals as the significant products for the future periods of Turkey. Therefore Turkey's export structure began to shift from labour and raw intensive goods to capital intensive goods. As it is expected Turkey is more competitive in CIS market than world market and has comparative advantage not only in agricultural products, food, manufactures, automotive products, textile and clothing as the world market but also in chemicals, pharmaceuticals, machinery and transport equipment, office and telecom equipment, telecommunications equipment. Products which have increasing comparative advantage vis a vis CIS countries are manufactures, chemicals, machinery and transport equipment, automotive products and textile. Although Turkey's comparative advantage in textile decreases in world market, its comparative advantage increase significantly with respect to CIS throughout the period.

CIS countries exhibit similar comparative advantages in the world market. In cross-country comparisons CIS countries have comparative advantage particularly in fuels and mining products, agricultural products, food, fuels, iron and steel but their dominance and positive contribution to the export performance have been decreasing or losing in the considering 
period. While Russia, Belarus, Georgia, Kazakhstan and Azerbaijan have a decreasing comparative advantage in fuels and mining products, Ukraine lost its competitiveness and Kyrgyz Republic became competitive for the last three years. Similarly Russia, Belarus, Kazakhstan and Azerbaijan have a decreasing comparative advantage in fuels and Georgia lost its comparative advantage whereas Kyrgyz Republic has been comparative advantage since 2006. Countries which have decreasing comparative advantage in iron and steel are Russia, Ukraine, Belarus, Georgia and Kazakhstan. While most of the CIS countries have decreasing comparative advantage in agricultural products such as Moldova, Belarus, Georgia or lost their competitiveness such as Kazakhstan and Azerbaijan; Kyrgyz Republic has increasing comparative advantage after 2005. Ukraine and Kyrgyz Republic has increasing comparative advantage in food sector whereas Moldova, Belarus and Georgia have decreasing comparative advantage. While Belarus lost its comparative advantage in clothing and textile, its comparative advantage increased in chemicals, on the other hand Moldova has increasing comparative advantage both in clothing and textile and Kyrgyz Republic also became competitive in clothing after 2005.

The IIT index results indicate that Turkey approaches intra-industry specialization not only raw materials (agricultural products and food) and labour intensive good textile but also capital intensive manufacture products such as iron and steel, telecommunications equipment, machinery transport and automotive products especially after 2001. ITT values reveal that Turkish economy has increasing inter-industry specialization mainly in capital intensive manufacture products and food. CIS countries' economy indicates the characteristics of increasing intra-industry trade in agriculture products and food (for Russia, Ukraine, Moldova, Belarus, Kazakhstan and Azerbaijan), manufactures (for Russia, Ukraine and Moldova) iron and steel (for Belarus, Georgia and Kazakhstan). Textile, fuels, automobile products, fuel and mining are sectors which an increase observed in their IIT index only in Belarus. Economic liberalization and integrations increase IIT level of the countries. Increasing value of ITT in manufacture goods imply the economic development and gains from the world trade.

It is found that there is an intense relationship throughout the period between Turkey and CIS countries with the exception of Belarus that implies an 'intense' trade relationship larger than the countries importance in world trade. Bilateral trade flow between Turkey and Azerbaijan, Kyrgyz Republic and the Georgia is extremely larger than these countries' importance in world trade. While trade intensity between Turkey and Russia, Ukraine, Kazakhstan decreased over the period, it is increased between Turkey and Moldova. To sum up the index results indicate that Turkey is one of the important trade partners of the CIS countries after the dissolution of the Soviet Union except Belarus.

\section{References}

- Balassa, 1965. "Trade Liberalization and 'Revealed' Comparative Advantage", The Manchester School, 33, p. 99-123.

- $\quad$ Erlat, Erlat, and Şenoğlu, 2007. "Measuring Vertical And Horizontal Intra-Industry Trade: The Case for Turkey", presented at the 6th International Conference of the Middle East Economic Association, March 14-16, 2007, Zayed University, Dubai, p.1

- $\quad$ Fertö and Hubbard, 2003. "Revealed Comparative Advantage and Competitiveness in Hungarian Agri-Food Sectors", The World Economy, 26, p. 250

- Grubel and Lloyd, 1971. "The Empirical Measurement of Intra-Industry Trade." Economic Record, 47, p.494 517.

- Havrila, and Gunawardana, 2003. "Analyzing Comparative Advantage and Competitiveness: An Application to Australia's Textile and Clothing Industries", Australian Economic Papers, 42, p.108

- Hoekman et.al., 2003). 
- Turk Stat, 2010. "Foreign Trade Statistics", http://www.TUİ.gov.tr/disticaretapp/Basla.do

- Utkulu and Seymen, 2004. "Revealed comparative advantage and competitiveness: Evidence for Turkey vis-a' -vis the EU 15", presented at the European Study Group 6th Annual Conference, Nottingham, p.8

- WTO, 2003. Trade Policy Review Turkey Report by the Government, , 19 November, p.29

- WTO, 2010. International Trade Statistics 2009,

- $\quad$ http://www.wto.org/english/res_e/statis_e/its2009_e/its09 merch trade_product e.ht $\underline{\mathrm{m}}$

- Yllmaz, 2003. “Turkey's Competitiveness in the European Union: A Comparison with Five Candidate Countries - Bulgaria, The Czech Republic, Hungary, Poland, Romania - and the EU15", Ezoneplus Working Paper, 12, p.13 